\title{
SEED CONDITIONING OF RED OAK: A RECALCITRANT NORTH AMERICAN SEED
}

\author{
D.K. STRUVE \\ Dept. of Horticulture and Crop Science, The Ohio State University, Columbus, OH, 43210-1086, USA.
}

\begin{abstract}
A ten day aerated water soak was developed as a seed conditioning treatment for red oak (Quercus rubra L.). Conditioned seeds had higher germination completeness, uniformity and speed compared to control seeds. Seeds could be conditioned under a wide range of temperatures and durations. Conditioned seeds were maintained at $7^{0} \mathrm{C}$ for 30 days without loss of seed quality. During conditioning, pericarps split in response to seed hydration. Split pericarps could be used as a pre-sowing indicator for high quality seeds. Seed conditioning was ineffective on dormant seeds. Increased crop uniformity and higher stand establishment can be realized by subjecting red oak acorns to an aerated water soak treatment followed by selecting seeds with split pericarps. These results are especially important in container production systems where limited numbers of value seeds are available. Key Words: Quercus rubra, acorns, stratification, aerated water soak, germination capacity, seed storage, seedling quality
\end{abstract}

\section{CONDICIONAMENTO DE SEMENTES DE CARVALHO VERMELHO: SEMENTE RECALCITRANTE DA AMÉRICA DO NORTE}

RESUMO: Sementes de carvalho vermelho (Quercus rubra L.) foram condicionadas diretamente em água, sob aeração, durante 10 dias. As sementes condicionadas fisiologicamente apresentaram maior percentagem, velocidade e uniformidade de germinação, quando comparadas com a testemunha. $O$ condicionamento das sementes pode ser efetuado sob ampla variação de temperaturas e períodos de exposição. Sementes condicionadas podem ser mantidas a $7^{\circ} \mathrm{C} / 30$ dias, sem perda de qualidade. Durante o condicionamento ocorre ruptura do pericarpo, em resposta à hidratação da semente; essa ocorrência pode ser utilizada para estimar a qualidade da semente. $O$ condicionamento não apresentou efeitos em sementes dormentes. $O$ condicionamento das sementes de carvalho vermelho em água, com aeração, seguido pela seleção de sementes com ruptura do pericarpo, proporciona o rápido estabelecimento e uniformidade das plântulas.

Descritores: Quercus rubra, semente, condicionamento fisiológico, avaliação da qualidade, armazenamento

\section{INTRODUCTION}

Seeds are the most widely used method of producing planting stock for artificial reforestation. Thus, seed quality is essential for artificial reforestation programs. There are many aspects of seed quality that affect seedling production including genetic purity, viability, vigor and dormancy. Seed conditioning improves germination completeness, uniformity and speed of germination in annual crops (Khan, 1993; Parera \& Cantliffe, 1994) and coniferous species (Edwards, 1986; Huang and Zou, 1989; Huang, 1989; Poulsen, 1996), but limited research has been done with hardwood species, especially recalcitrant species.

Several seedling production challenges exist with northern temperate recalcitrant species such as oaks (Quercus spp.).They are commercially important in eastern North American forests. Oak seeds (fruits) are recalcitrant (Pritchard, 1991). Flower initiation and seed and fruit development occur over an extended time. With members of the 
Erythrobalanus subgenera, the reproductive process occurs over three growing seasons. Flower initiation and seed and fruit development are affected by weather conditions and the extended fruit development period exposes the fruit to seed pests. Individual trees have an innate alternate bearing habit; large seed crops occur irregularly at three to 10 year intervals (Young \& Young, 1992). Thus, seed and seedling quanities vary significantly from year-to-year. By definition, the seeds (fruits) have high moisture content at maturity (20 to $30 \%$ ) and can not tolerate dessication without loss of viability. Satisfactory seed storage conditions, where high seed viability is maintained for an extended time, have not been identified. To date, conditions that maintain seed quality (presence of oxygen, 0 to $7^{\circ} \mathrm{C}$ and high relative humidity; stratification conditions) also satisfy embryo dormancy. Thus, extended stratification/storage conditions result in seed germination, reduced seed quality and ease of handling.

There are two separate seed dormancy mechanisms within the Quercus genus. Within the Leucobalanus subgenus, there is no radicle dormancy, but there is epicotyl dormancy. Thus, root emergence occurs in the fall but shoot growth is delayed until spring after prolonged exposure to chilling temperatures $\left(0\right.$ to $\left.7^{\circ} \mathrm{C}\right)$. Within the Erythrobalanus subgenus, both epicotyl and hypocotyl dormancy exist and root and shoot emergence occur in spring following cold stratification (Vogt, 1974).

Additional challenges exist in other species. In Chionanthus virginicus and Stewartia pseudocamelia, flower and seed development occur over an extended period resulting in differences in seed maturation and fruit maturity, and deepness of dormancy at a particular calendar date. Chionanthus virginicus seed illustrate the variation in deepness of dormancy that can exist within seed collected from the same tree. Germination occurred over a five month period; however, even after five months, over $20 \%$ of the sound seed had not germinated (Figure 1). Variation in seed maturity also occurs in annuals such as broccoli, Brassica oleracea (Jett \& Welbaum, 1996). In Stewartia pseudocamelia, seed germination occurred over a 30 month period (Struve, unpublished data). Thus, a predictable, uniform yearly supply of seedlings for these species is difficult.

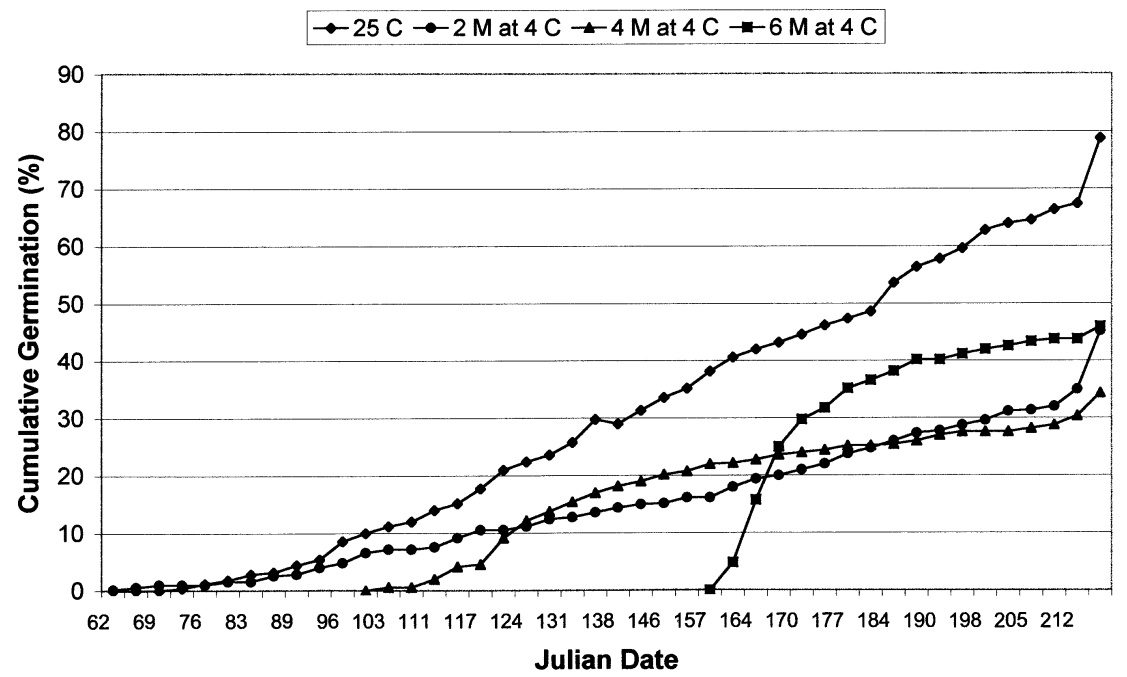

Figure 1 - Cumulative percent germination of Chionanthus virginicus seed given various lengths of exposure (2, 4 or 6 months, $2 \mathrm{M}$ at $4^{\circ} \mathrm{C}, 4 \mathrm{M}$ at $4^{\circ} \mathrm{C}$ and $6 \mathrm{M}$ at $4^{\circ} \mathrm{C}$, respectively) to cold $\left(4^{\circ} \mathrm{C}\right)$ stratification conditions before conducting a germination test at $25^{\circ} \mathrm{C}$. Control seeds $\left(25^{\circ} \mathrm{C}\right)$ were held at a constant $25^{\circ} \mathrm{C}$. Each value is the mean of four 100 seed replications. 
Finally, even though the nursery manager may succeed in producing a crop of seedlings, many of the important North American hardwood species are difficult to transplant and establish (Crow, 1988; Johnson et al., 1986; Teclaw \& Isebrands, 1993; Weaver \& Spiecker, 1993; Zaczek et al., 1993). Therefore, hardwood seed production, seed harvest, and seedling production must be approached as a coordinated system where all aspects from flower initiation to seed development, harvest, and storage to seedling production, transplanting and establishment are integrated. The best approach to insure predictable amounts of high quality seed and seedlings is to establish and manage seed orchards and use container production.

This study describes a seed conditioning system for red oak, a recalcitrant North American species. The goals of the research were to develop a seed conditioning treatment that insures high germination completeness, results in rapid and uniform germination, and to develop a pre-sowing technique to identity high quality seeds.

\section{MATERIALS AND METHODS}

The materials and methods of the red oak experiments were as described in Struve et al. (1991) and Cooper et al., 1991. Unreported in those studies were preliminary tests conducted to identify the optimum osmotic solution and priming duration and an experiment to determine the optimum conditioning temperature and duration. For both studies, acorns were collected locally in the fall, placed in plastic bags and stratified at $7^{\circ} \mathrm{C}$ until used in experiments the following spring. Experiments were conducted in spring, after approximately 150 days stratification. For the initial priming experiment, 30 acorns were randomly selected and placed in tubes for priming according to Akers \& Holley (1986). The acorns were primed for 14 days in water, $1.5 \%$ or $3.0 \% \mathrm{KNO}_{3}$, or $31 \%$ (g/vol.) PEG 6000 . The number of acorns with split pericarps was recorded daily. Following the priming treatment, acorns from the PEG and water treatments were placed in germination boxes and germinated in the dark at $25^{\circ} \mathrm{C}$ and $100 \%$ relative humidity. Seeds were counted as germinated when the radicle exceed $2.5 \mathrm{~cm}$ in length.

For determining the optimum conditioning temperature and duration, acorns were placed in a factorial combination of four temperatures $(0,10$, 20 and $\left.30^{\circ} \mathrm{C}\right)$ and five durations $(3,6,9,12$ and 15 days). Each treatment combination used five 20 seed replications for the germination test.

\section{RESULTS AND DISCUSSION}

The rate of pericarp splitting was most rapid and greatest in acorns primed in water and PEG 6000 (Figure 2). The rate of pericarp splitting was less in both $\mathrm{KNO}_{3}$ solutions. No acorns germinated during the priming treatment. Further, acorns primed in $\mathrm{KNO}_{3}$ were dead as evidenced by their discoloration and decayed appearance. The germination pattern

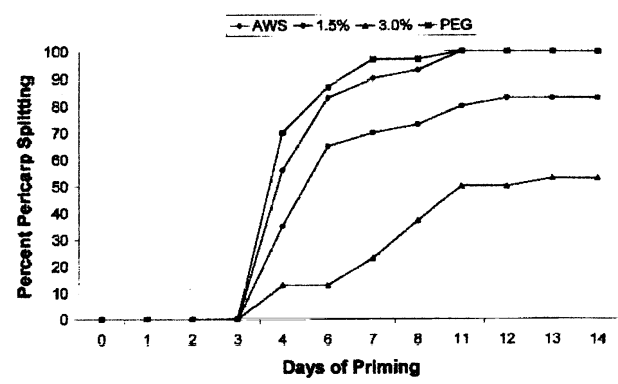

Figure 2 - Cumulative percent split pericarps of red oak acorns primed in water (aerated water soak, AWS $), 1.5$ or $3.0 \% \mathrm{KNO}_{3}(1.5 \%$ and $3 \%$, respectively) or $31 \%$ (g/vol.) polyethylene glycol 6000 (PEG) for 14 days at $25^{\circ} \mathrm{C}$. Each value is the mean of two 50 seed replications.

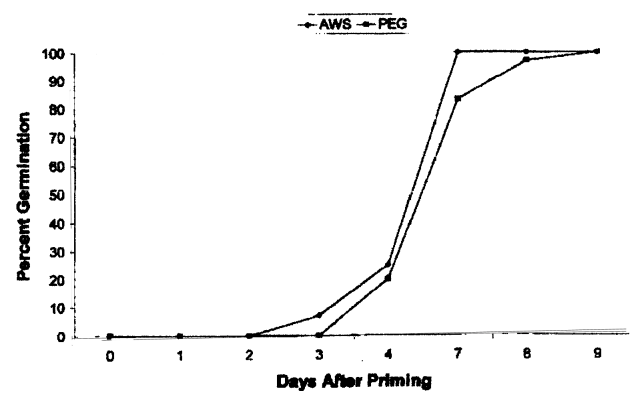

Figure 3 - Cumulative percent germination of red oak acorns after priming in an aerated water soak (AWS) or $31 \%$ (g/vol.) polyethylene glycol 6000 (PEG) for 14 days at $25^{\circ} \mathrm{C}$. Each value is the mean of two 50 seed replications. 
for acorns primed in water and PEG 6000 was similar (Figure 3). Based on these results, a 14 day (later reduced to 10 days) aerated water soak treatment was used to condition seeds in subsequent experiments.

The aerated water soak treatment increased germination completeness and uniformity (Struve et al., 1991) similar to other seed conditioning treatments used on orthodox seeds (Khan, 1993; Parera \& Cantliffe, 1994; Poulsen, 1996). However, seed moisture content of unprimed red oak seeds was similar to seed moisture content of conditioned orthodox seed (Bonner, 1968; Khan, 1993; Poulsen, 1996; Pritchard, 1991). During priming, seed moisture content increased $15 \%$ over non-primed seeds from an average of 38 to $53 \%$. In Aesculus indica, a recalcitrant species, germination occurred at 57\% moisture content (Uniyal \& Nautiyal, 1996).

The red oak experiment used three half-sib families. The percentage increase in moisture content was different for each half-sib family, ranging from 12 to $19 \%$, which illustrates a general principle. In unselected populations, there are usually significant differences among families in germination characteristics. Thus, a significant source of variation can be attributed to the mother tree.

Aerated water soaked seed could be maintained for 30 days at $7^{\circ} \mathrm{C}$ without significantly reducing seed quality while longer durations significantly reduced seed quality (Struve et al., 1991). Unlike orthodox seeds which can be redried and stored after conditioning (De Matos Malavasi et al., 1985; Pence, 1996; Poulsen, 1996), recalcitrant seeds cannot be stored for extended periods after an aerated water soak treatment. There is a narrow window of time between completion of seed conditioning and sowing recalcitrant seeds before seed quality is reduced.

During the aerated water soak treatment, pericarps split in response to increased seed hydration, as also reported by Bonner (1968). It was found that pericarp splitting could be used as an indicator of seed quality (Cooper et al., 1991). Pericarp splitting began after two days of conditioning and reached $90 \%$ of the final value after four days in the aerated water soak treatment. Further, those acorns where the pericarp had split had significantly higher germination values that those acorns where the pericarp remained intact.
Thus, pericarp splitting could be used as a presowing indicator of high quality seeds.

The benefits of the aerated water soak treatment were realized only after seed dormancy had been broken (Cooper et al., 1991). Acorns given an aerated water soak treatment in the fall before exposure to stratification conditions had low germination value if placed immediately in a germination test following treatment. A fall aerated water soak treatment increased seed moisture content approximately $10 \%$. If acorns were given an aerated water soak treatment in the fall and then cold stratified, seed quality was reduced compared with acorns given an aerated water soak treatment after cold stratification. The fall aerated water soak treatment did not break dormancy. Conditioning treatments to dormant red oak seeds are, therefore, ineffective.

Red oak seeds could be conditioned over a wide range of temperatures and durations (Figure 4). Germination completeness ranged from 89 to $17 \%$ for nine days at $10^{\circ} \mathrm{C}$ and 15 days at $30^{\circ} \mathrm{C}$, respectively. Germination was rapid; $90 \%$ of final germination occurred within six days for all treatment combinations except the control and three days at $0^{\circ} \mathrm{C}$.

\section{CONCLUSIONS}

Red oak is a recalcitrant species. Priming treatments such as $\mathrm{KNO}_{3}$, which are used successfully to prime orthodox seeds cannot be used to prime red oak acorns. This may be due to large seed size as priming large seed in $\mathrm{KNO}_{3}$ has decreased seed quality (Khan, 1993). The aerated water soak period for red oak is longer than that used for vegetable seeds, six to 10 days compared to two to four days (Parera \& Cantliffe, 1994) or two to seven days (Khan, 1993). A 10 day aerated water soak treatment resulted in red oak acorns having germination characteristics similar to primed orthodox seeds including increased germination completeness, speed and uniformity. Aerated water soak treatments are not effective unless dormancy has been broken by cold stratification. Acorns with split pericaps following the aerated water soak treatment have high germination capacity and can be used as a pre-sowing selection technique for high quality seeds. 

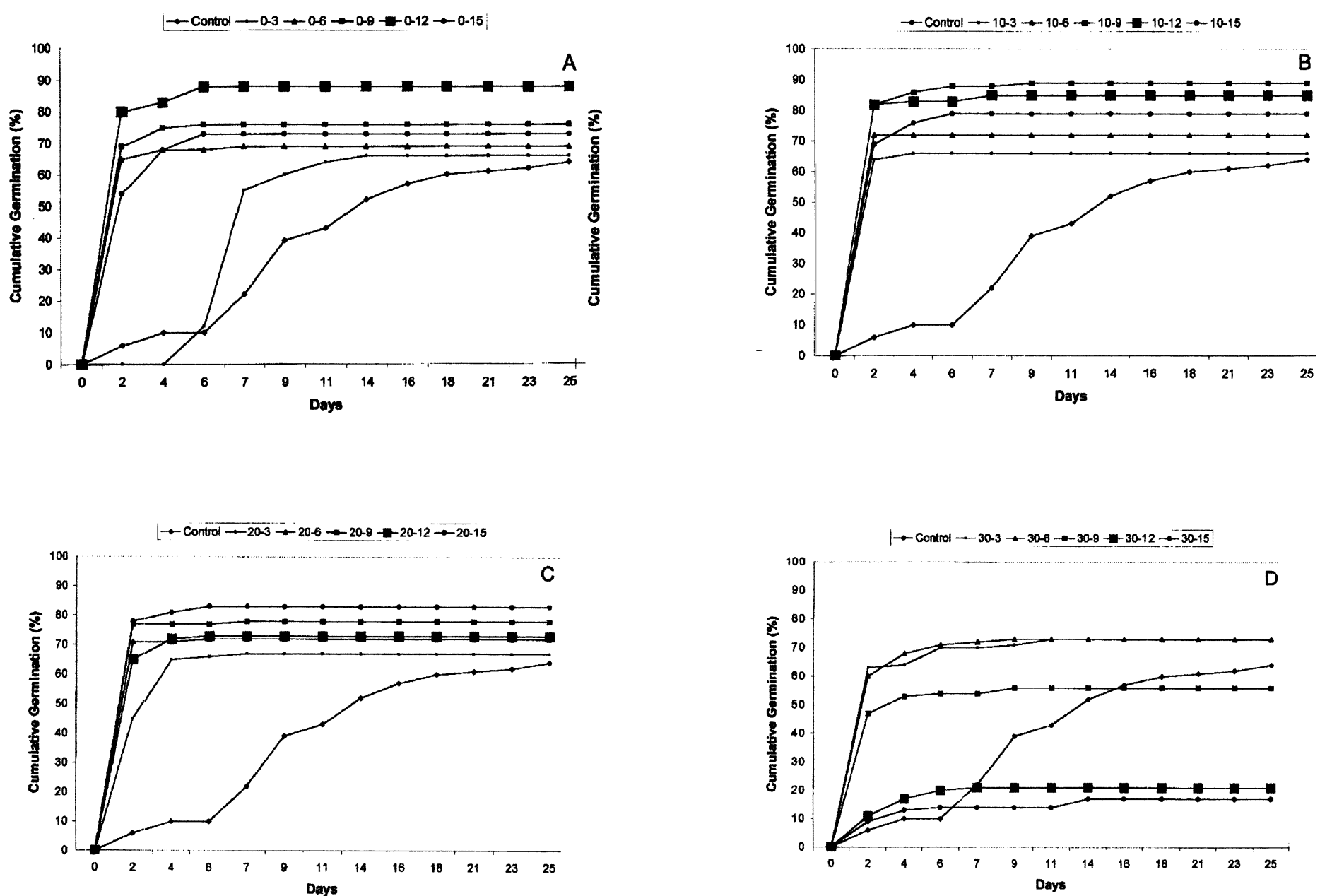

Figure 4 - Cumulative germination of red oak give an aerated water soak at four temperatures $\left(0,10,20\right.$ and $30^{\circ} \mathrm{C}$, Figures A, B, C and D, respectively) for five durations $(3,6,9,12$ or 15 days). Seed taken directly from stratification conditions served as a control. Each value is the mean of five 20 seed replications. 


\section{REFERENCES}

AKERS, S.W.; HOLLEY, K.E. SPS: A system for priming seeds using aerated polyethylene glycol or salt solutions. HortScience, v.21: 529-531, 1986.

BONNER, F.T. Water uptake and germination of red oak acorns. Botanical Gazette, v.129, p.83-85, 1968.

COOPER, C.; STRUVE, D.K.; BENNETT, M.A. Pericarp splitting after aerated water soak can be used as an indicator of red oak seed quality. Canadian Journal of Forest Research, v.21, p.1694-1697, 1991.

CROW, R.T. Reproductive mode and mechanisms for self-replacement of northern red oak (Quercus rubra): a review. Forest Science, v. 34, p.19-40, 1988.

DE MATOS MALAVASI; STRAFFORD, S.G.; LAVENDER, D.P. Stratifying, partially redrying and storing Douglas-fir seeds: effects on growth and physiology during germination. Annales des Sciences Foresties, v.42, p.371-384, 1985.

EDWARDS, D.G.W. Special prechilling techniques for tree seeds. Journal Seed and Techology, v.10, p.151-171, 1986.

HUANG, Y.G.; ZOU, Q. Effects of osmoconditioning and drying on germination of Pinus sylvestris var. mongolica and Larix gmelinii seeds. Seed Science and Technology, v.17, p.235-242, 1989.

HUANG, Y.G. Enhancing tolerance of lodgepole pine and white spruce seeds to thermo-hygro-stresses by osmoconditioning. Seed Science and Technology, v.17, p.341-353, 1989.

JETT, L.W.; WELBAUM, G.E. Changes in broccoli (Brassica oleracea L.) Seed weight, viability, and vigour during development and following drying and priming. Seed Sci.ence and Technology, v.24, p.127-137, 1996.

JOHNSON, P.S., DALE, C.D.; DAVIDSON, K.R.; LAW, J.R. Planting northern red oak in the Missouri Ozarks: a prescription. North. J. Appl. For. , v.3,p.66-68, 1986.
KHAN, A.A. Preplant physiological seed conditioning. Horticultural Reviews, v.13, p.131-182, 1993.

PARERA, C.A.; CANTLIFFE, D.J. Presowing seed priming. Horticultural Reviews, v.16, p.109-142, 1994.

PENCE, V.C. Germination, desiccation and cryopreservation of seeds of Populus deltoides Bartr. Seed Science and Technology, v.24, p.1511-157, 1996.

POULSEN, K.M. Prolonged cold, moist pretreatment of conifer seeds at controlled moisture content. Seed Science and Technology, v.24, p.75-87, 1996.

PRITCHARD, H.W. Water potential and embryonic axis viability in recalcitrant seeds of Quercus rubra. Annals of Botany, v.67, p.43-47, 1991.

STRUVE, D.K.; DRESS, M.F.; BENNETT, M.A. Aerated water soak increases red oak seed germination and seedling emergence. Canadian Journal of Forest Research, v.21, p.1257-1261, 1991.

TECLAW, R.M.; ISEBRANDS, J.G. An artificial regeneration system for establishing northern red oak on dry-mesic sites in the Lake States, USA. Annales des Sciences Foresties, v.50, p.543-552, 1993.

UNIYAL, R.C.; NAUTIYAL, A.R. Physiology of seed development in Aesculus indica, a recalcitrant seed. Seed Science and Technology, v.24, p.419-424, 1996.

VOGT, A.R. Physiological importance of changes in endogenous hormones during red oak acorn stratification. Forest Science, v.20, p.187-191, 1974.

WEAVER, G.T.; SPIECKER, H. Silviculture of highquality oaks: questions and future research needs. Annales des Sciences Foresties, v.50, p.531-534, 1993.

YOUNG, J. A.; YOUNG, C.G. Seeds of Woody Plants in North America. Portland: Dioscordies, 1992. $407 \mathrm{p}$. 
ZACZEK, J.J.; STEINER, K.C.; BOWERSOX, T.W. Performance of northern red oak planting stock. North. J. Appl. For., v.10, p.105-111, 1993.
Recebido para publicação em 10/07/98 Aceito para publicação em 03/08/98 